\title{
METABOLIC "FOOTPRINTS" OF THE CIRCULATING CANCER MUCINS: CA125 IN THE HIGH-GRADE OVARIAN CANCER
}

Chagovets $\mathrm{W}^{1} \bowtie$, Vasil'ev VG², lurova $\mathrm{MV}^{1,3}$, Khabas GN ${ }^{1}$, Pavlovich $\mathrm{SV}^{1,3}$, Starodubtseva $\mathrm{NL}^{1}$, Mayboroda OA ${ }^{4,5}$

${ }^{1}$ Kulakov National Medical Research Center for Obstetrics, Gynecology and Perinatology, Moscow, Russia

2 Peoples' Friendship University of Russia, Moscow, Russia

${ }^{3}$ Sechenov First Moscow State Medical University, Moscow, Russia

${ }^{4}$ Leiden University Medical Center, Leiden, The Netherlands

${ }^{5}$ Tomsk State University, Tomsk, Russia

\begin{abstract}
Mucins are large glycoproteins characterized by the abundant O-linked oligosaccharides (O-glycans) clustered on a protein backbone. Most of the circulating mucins are rapidly cleared by glycan-recognizing hepatic clearance receptors in the liver. Those mucins that remain in the bloodstream are most commonly used as markers in clinical diagnostics. One of such circulating mucins is MUC16; a peptide epitope of which is known as CA125 antigen — a marker for ovarian cancer. Here, using a targeted $1 \mathrm{H}-\mathrm{NMR}$ profiling of plasma we are exploring a link between the measured CA125 values and the systemic metabolism of the patients within a group with confirmed high-grade ovarian cancer. The study allowed identifying statistically significant associations between the measured values of CA125 epitope and the plasma concentrations of glucose, glutamine, alanine, betaine and serine. The significance of the identified associations for the listed compounds is below 0.01 . This, in turn, enables us to hypothesize about a possibility of including the metabolic measures into a composite score of the ovarian cancer based on the CA125 epitope of MUC16.
\end{abstract}

Keywords: metabolomics, NMR, circulating mucins, CA125, ovarian cancer

Funding: the study was supported by a grant from the Russian Science Foundation (project \#20-65-46014).

Author contribution: Chagovets W — study planning, sample preparation, discussion of NMR data processing, manuscript authoring and editing; Vasil'ev VG — sample preparation, NMR analysis; lurova MV, Khabas GN — collection and characterization of clinical samples, discussion of the results; Pavlovich SV — study research, discussion of the results; Starodubtseva NL — study planning, clinical data processing; Mayboroda OA — study planning and management, manuscript authoring, NMR data processing.

Compliance with ethical standards: the study was approved by the Ethics Committee of the V.I. Kulakov National Medical Research Center for Obstetrics, Gynecology and Perinatology (Minutes \#10 of December 05, 2019), conducted in accordance with federal laws of the Russian Federation (\#152, 323 etc.) and the Declaration of Helsinki of 1964 with all subsequent extensions and amendments regulating scientific research involving biomaterials obtained from human beings.

$\triangle$ Correspondence should be addressed: Vitaly V. Chagovets

Akademika Oparina, 4, Moscow, 117997, Russia; vvchagovets@gmail.com

Received: 01.12.2021 Accepted: 16.12.2021 Published online: 29.12.2021

DOI: $10.24075 /$ brsmu.2021.065

\section{МЕТАБОЛОМНАЯ ПОДПИСЬ СВОБОДНЫХ МУЦИНОВ ПРИ ОНКОЛОГИЧЕСКИХ ЗАБОЛЕВАНИЯХ: СА125 И РАК ЯИЧНИКОВ ВЫСОКОЙ СТЕПЕНИ ЗЛОКАЧЕСТВЕННОСТИ}

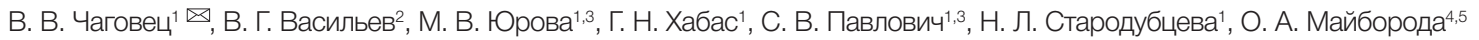

${ }^{1}$ Национальный медицинский исследовательский центр акушерства, гинекологии и перинатологии имени В. И. Кулакова, Москва, Россия

2 Российский университет дружбы народов, Москва, Россия

${ }^{3}$ Первый Московский государственный медицинский университет имени И. М. Сеченова, Москва, Россия

${ }^{4}$ Медицинский центр Лейденского университета, Лейден, Нидерланды

5 Томский государственный университет, Томск, Россия

Муцины - это высокомолекулярные гликопротеины, характерной чертой которых является большое количество О-связанных олигосахаридов (О-гликанов), присоединенных к белковому остову. Основная часть циркулирующих муцинов быстро выводится с помощью рецепторов печени, распознающих гликаны. Муцины, которые не выводятся из организма и остаются в кровотоке, наиболее часто используют в качестве клинических диагностических маркеров. Пептидный эпитоп одного из таких циркулирующих муцинов, называемого MUC16, известен как антиген СА125, маркер рака яичников. Целью работы было провести профилирование метаболитов плазмы с помощью 1Н-ЯМР анализа и изучить связь между измеренными значениями СA125 и системным метаболизмом пациентов в группе с подтвержденным раком яичников высокой степени злокачественности. В результате исследования были обнаружены статистически значимые ассоциации между измеренными значениями эпитопа СА125 и концентрациями глюкозы, глутамина, аланина, бетаина и серина в плазме. Значимость выявленных ассоциаций для перечисленных соединений меньше 0,01. Это позволяет выдвинуть гипотезу о возможности включения метаболических показателей в диагностику рака яичников.

Ключевые слова: метаболомика, ЯМР, циркулирующие муцины, СА125, рак яичников

Финансирование: исследование выполнено за счет гранта Российского научного фонда (проект № 20-65-46014).

Вклад авторов: В. В. Чаговец - планирование исследования, подготовка образцов, обсуждение обработки данных ЯМР, написание и редактирование рукописи; В. Г. Васильев - пробоподготовка, ЯМР-анализ; М. В. Юрова, Г. Н. Хабас - сбор и характеристика клинических образцов, обсуждение результатов; С. В. Павлович — планирование исследования, обсуждение результатов; Н. Л. Стародубцева - планирование исследования, обработка клинических данных; О. А. Майборода — планирование исследования и руководство им, написание рукописи, обработка данных ЯМР

Соблюдение этических стандартов: исследование одобрено этическим комитетом Национального медицинского исследовательского центра акушерства, гинекологии и перинатологии имени В. И. Кулакова (протокол № 10 от 05 декабря 2019 г.), проведено в соответствии с федеральными законами Российской Федерации (№№ 152, 323 и др.) и Хельсинкской декларацией 1964 г. со всеми последующими дополнениями и изменениями, регламентирующими научные исследования на биоматериалах, полученных от людей.

$\bowtie$ Для корреспонденции: Виталий Викторович Чаговец ул. Академика Опарина, д. 4, г. Москва, 117997, Россия; vvchagovets@gmail.com

Статья получена: 01.12.2021 Статья принята к печати: 16.12.2021 Опубликована онлайн: 29.12.202

DOI: $10.24075 /$ vrgmu.2021.065 
Mucins are large glycoproteins characterized by the abundant O-linked oligosaccharides (O-glycans) clustered on a protein backbone. They are usually localized on the surface of the epithelium, but potential sites of proteolytic cleavage are found in most mucin genes, which explains their appearance in the systemic circulation [1]. Most of the circulating mucins are rapidly cleared by glycan-recognizing hepatic clearance receptors in the liver. Those which evade the clearance and remain in the circulation are the most frequently used as the clinical diagnostic markers. One of such circulating mucins is MUC16; its peptide epitope is known as the CA125 antigen, a marker of ovarian cancer [2]

CA125 has been known for over three decades [3]. A number of large-scale clinical studies have evaluated the potential use of serum CA125 as a marker of ovarian cancer (OC). While the structural identity of the epitope remains elusive and its practical value is being challenged from time to time [4], CA125 remains the only clinically reliable diagnostic marker of ovarian cancer [5]. Here, however, we are not going to question the diagnostic value of the CA125 epitope. We address a different question, namely to which extend the CA125 values can be associated with a metabolic status of the patients. Ever since Otto Warburg discovery of the tumor cells altered metabolism a view of the cancer as a metabolic disease is steadily gaining acceptance [6]. Indeed, there is strong evidence that increased glucose consumption and increased lactate secretion in tumors promote their growth [7]. As the tumor grows, so does its need for bioenergetic resources and structural blocks. This growing need changes the systemic metabolism, which can be seen in the patient's blood. Thus, we hypothesize that the measured values of the CA125, as a tumor marker, will have their correlates or "footprint" in the metabolic profile of plasma. To test this hypothesis, we applied targeted $1 \mathrm{H}-\mathrm{NMR}$ profiling within a homogeneous selection of the patients with confirmed high-grade ovarian cancer. To find these correlates or associations, we applied an approach based on the multiple linear models adjusted for confounding variables (age and body mass index of a patient in our case).

\section{METHODS}

The study included 67 patients with histologically verified high-grade $(H G)$ serous OC. They donated venous blood plasma samples immediately before the operation, before administration of antibacterial, analgesic and other drugs.

The inclusions criteria were: age over 18 years; histological verification of the diagnosis ( $\mathrm{HG}$ serous OC, stage I-IV as per the FIGO (International Federation of Gynecology and Obstetrics) scale).

The non-inclusion criteria were: age below 18 years; 6 or more months of intake of hormonal drugs (combined oral contraceptives, hormone replacement therapy or menopausal therapy); US-confirmed pathology of pelvic organs and/or manifestations of the already diagnosed reproductive diseases; proliferative processes; active cancer at the time of the study or in history (any nosology other than the one studied); pelvic organ surgery; various histotype neoplasms in one patient; pregnancy.

Table 1. Age and BMI of the patients with I-II and III-IV stages of HG OC (no statistically significant differences found; the method used is the Mann-Whitney U-test)

\begin{tabular}{|c|c|c|c|c|c|c|}
\hline \multirow{2}{*}{ HGOC stage } & \multicolumn{2}{|c|}{ Age, years } & \multirow{2}{*}{$p$} & \multicolumn{2}{|c|}{$\mathrm{BMI}, \mathrm{kg} / \mathrm{m}^{2}$} & \multirow{2}{*}{$p$} \\
\cline { 2 - 3 } \cline { 5 - 6 } & $\mathrm{Me}$ & $\mathrm{Q}_{1}-\mathrm{Q}_{3}$ & & $\mathrm{Me}$ & $\mathrm{Q}_{1}-\mathrm{Q}_{3}$ & \\
\hline $\mathrm{II-II}$ & 53 & $46-59$ & \multirow{2}{*}{0.51} & 24 & $21-27$ & $23-28$ \\
\hline III-IV & 54 & $49-61$ & & 25 & 23 \\
\hline
\end{tabular}

The exclusion criteria were: histotype of the malignant ovarian tumor different from HG OC or concomitant thereto, as established through repeated examination of histological micropreparations; primary multiple neoplastic diseases not identified at the time the patient applied to the Center seeking assistance about ovarian oncoma (data on the presence thereof were obtained during the post-surgery observation).

The quantity of CA125 tumor marker in blood samples was established through the enzyme immunoassay analysis.

\section{Preparation of samples for NMR analysis}

All chemicals used in the buffers were purchased from Sigma-Aldrich (USA), with the exception of $\mathrm{D}_{2} \mathrm{O}$ heavy water (Cortecnet; France) and 3-(trimethylsilyl) propionic-2,2,3,3-d4 acid sodium salt (TSP) (Cambridge Isotope Laboratories Inc., UK). We made two buffer solutions. Buffer A was a sodium phosphate buffer in $\mathrm{H}_{2} \mathrm{O} / \mathrm{D}_{2} \mathrm{O}(80 / 20)$ with $\mathrm{pH} 7.4$, containing $6.15 \mathrm{mmol} / \mathrm{L} \mathrm{NaN3}$ and $4.64 \mathrm{mmol} / \mathrm{L}$ TSP. Buffer B was a sodium phosphate buffer in $\mathrm{D}_{2} \mathrm{O}(\mathrm{pH} 7.4)$, containing 1.5 $\mathrm{mol} / \mathrm{L} \mathrm{K}_{2} \mathrm{HPO}_{4}, 2 \mathrm{mmol} / \mathrm{L} \mathrm{NaN3}$, and $4 \mathrm{mmol} / \mathrm{L}$ TSP. Ritter Deepwell 96-well plates were purchased from Novaveth BV (Netherlands), NMR tubes from Bruker Biospin Ltd (Germany). The plasma samples were thawed at $4{ }^{\circ} \mathrm{C}$ and mixed through 10 rotations of the tubes. After that, samples $(120 \mu \mathrm{l})$ were mixed with $120 \mu \mathrm{l}$ of buffer solution. For each sample, $190 \mu \mathrm{l}$ of buffer and plasma mixture were transferred to $5 \mathrm{~mm}$ tubes with the help of a modified Gilson 215 tube filling station, and then kept at $6^{\circ} \mathrm{C}$ in the sample changer.

$1 \mathrm{H}$ NMR data were collected using a Bruker $700 \mathrm{MHz}$ AVANCE NEO spectrometer equipped with a $5 \mathrm{~mm}$ Prodigy cryogenic probe head. A Bruker sample changer (Bruker; Germany) was used to feed and retrieve samples (according to the two NMR protocols: one for plasma samples and one for all other samples).

All experiments were recorded at $310 \mathrm{~K}$. A fresh sample of $99.8 \%$ methanol-d4 enabled temperature calibration. Axial shimming was automatically optimized before each measurement. Duration of $90^{\circ}$ pulses was automatically calibrated for each individual sample using a homonucleargated mutation experiment on the locked and shimmed samples after automatic tuning and matching of the probe head. For each plasma sample a Purcell-Meiboom-Gill (CPMG) experiment was recorded. A standard 1D CPMG pulse sequence with presaturation was used to for the acquisition of T2-filtered spectra. A pulse train of 128 refocusing pulses with individual spin echo delays of $0.6 \mathrm{~ms}$ was applied resulting in a total T2 filtering delay of $78 \mathrm{~ms}$. After applying 4 dummy scans, a total of 73,728 data points covering a spectral width of $12,019 \mathrm{~Hz}$ were collected.

\section{Identification and quantification of metabolites}

Metabolites were identified by searching the full 1D and 2D JRES data using the proprietary Bbiorefcode (Bruker Biospin Ltd; Germany).

\section{NMR analysis and spectral data processing}


The quantification of metabolites in blood samples was semi-automatic and relied on the Chenomx NMR Suite 9.0 software (Chenomx Inc; Canada). The results of this semiautomatic quantification were processed manually. The concentrations were calculated based on the known TSP concentration $(0.4 \mathrm{mmol} / \mathrm{L})$.

\section{Data analysis}

All data were analyzed in the R software environment (http:// www.r-project.org/, versions $R$ 4.1.1, 4.1.2). The initial processing of the data tables relied on the tidyverse (version 1.3.1) and readxl (1.3.1) packages. Ggplot2 (version 3.3.5) and ggforestplot (version 0.1.0) enabled visualization of the results.

\section{RESULTS}

The sample included 67 patients, of which 11 patients had stage I or II UG OC and 56 patients - stage III or IV HG OC. The patients were comparable by age and body mass index (BMI; Table 1). The median age of patients was $53(46 ; 59)$ years and $54(49 ; 61)$ years, which is comparable with the data of population studies [8]. The median BMls of the patients were $24(21 ; 27) \mathrm{kg} / \mathrm{m}^{2}$ and $25(23 ; 28) \mathrm{kg} / \mathrm{m}^{2}$.

Figure 1 shows a histogram of CA125 levels in the studied sample in the original (A) and logarithmic scales (B). The distribution based on raw values is strongly shifted to the right (median $200 \mathrm{U} / \mathrm{ml}$, mean $742.2 \mathrm{U} / \mathrm{ml}$ ). Thus, to remain within the basic assumptions of the linear models, we further used the log-transformed values of the CA125.

To get an overview of the plasma metabolites, we used a targeted $1 \mathrm{H}-\mathrm{NMR}$ profiling and quantified 33 metabolites. Table 2 summarizes their medians and interquartile range values. To expand the set of parameters related to the metabolic status of patients, a set of physiologically meaningful ratios was added to the data set. Those ratios could be useful for getting insight into the amino acids metabolism and enzymatic interconversions (e.g., alanine/glutamine), gluconeogenesis (e.g., alanine/ citrate), and ketogenesis (e.g., acetate/acetoacetate).

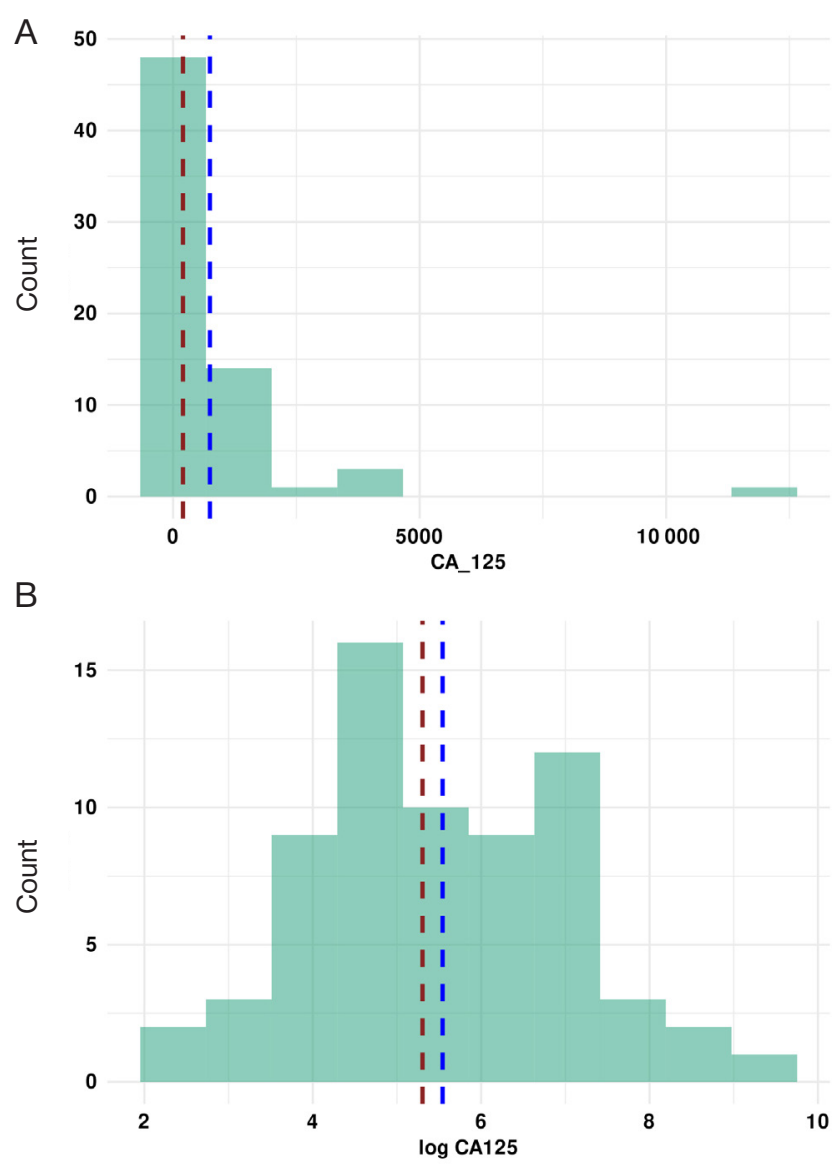

Fig. 1. CA125 levels histogram. A. baseline and logarithmic levels. B. The dark red line indicates the median and the blue line indicates the mean of the distribution

All the calculated ratios, their medians and interquartile rangeare summarized in the Table 3.

We used the linear regression models to study the relationships between metabolites and their correlations: the metabolites were used as the dependent variable and CA125

Table 2. List of quantified metabolites in plasma of patients with HG OC. The values are given as median/interquartile range and rounded to the nearest whole number

\begin{tabular}{|c|c|c|c|}
\hline Metabolite & Concentrations $(\mu \mathrm{M})$ Median (IQR) & Metabolite & Concentrations $(\mu \mathrm{M})$ Median (IQR) \\
\hline 2-Aminobutyrate & $41(27.55)$ & Glutamine & $310(241.407)$ \\
\hline 2-Hydroxybutyrate & $104(81.127)$ & Glycine & $149(106.229)$ \\
\hline 2-Oxoglutarate & 30 (18.48) & Isoleucine & $45(31.64)$ \\
\hline 3-Hydroxybutyrate & $206(122.460)$ & Isopropanol & $10(7.18)$ \\
\hline Acetate & $21(15.28)$ & Lactate & $1191(817.2000)$ \\
\hline Acetoacetate & 107 (55.199) & Leucine & $125(84.150)$ \\
\hline Acetone & $103(58.177)$ & Lysine & $91(62.115)$ \\
\hline Alanine & $185(114.251)$ & Methanol & 50 (35.63) \\
\hline Arginine & $89(65.130)$ & Pyruvate & $41(30.57)$ \\
\hline Betaine & $71(50.97)$ & Serine & 119 (89.155) \\
\hline Citrate & 38 (29.59) & Succinate & $24(6.53)$ \\
\hline Creatine & $33(20.46)$ & Threonine & $141(112.190)$ \\
\hline Creatinine & $40(29.48)$ & TMAO & $45(30.57)$ \\
\hline Ethanol & 35 (30.49) & Tyrosine & $42(28.57)$ \\
\hline Formate & 27 (20.35) & Valine & $168(108.201)$ \\
\hline Glucose & 3052 (2080.4199) & Myolnositol & 60 (45.82) \\
\hline Glutamate & 111 (81.156) & & \\
\hline
\end{tabular}

Note: IQR — Interquartile Range. 


\section{ОРИГИНАЛЬНОЕ ИССЛЕДОВАНИЕ І ОНКОЛОГИЯ}

Table 3. Summary of the calculated metabolite relationships. The values are given as median/interquartile range

\begin{tabular}{|c|c|c|c|}
\hline Ratio & Median (IQR) & Ratio & Median (IQR) \\
\hline Ala/Gln & $0.58(0.45,0.67)$ & Glc/Cit & $80(42,128)$ \\
\hline Ala/Leu & $1.54(1.19,1.94)$ & Gln/Cit & $9.7(4.5,13.8)$ \\
\hline Ala/lle & $3.98(2.99,5.08)$ & Glc/Pyr & $65(49,125)$ \\
\hline Ala/Tyr & $4.23(3.51,5.03)$ & Gln/Glc & $0.102(0.090,0.120)$ \\
\hline Ala/Val & $1.11(0.90,1.39)$ & Gln/Pyr & $7(5,12)$ \\
\hline GIn/Leu & $2.77(2.24,3.24)$ & Lac/Ala & $6.53(5.27,9.01)$ \\
\hline Gln/Ile & $7.10(5.58,8.47)$ & Lac/Cit & $32(16,55)$ \\
\hline Gln/Tyr & $7.51(6.34,9.85)$ & Lac/Glc & $0.38(0.31,0.53)$ \\
\hline $\mathrm{Gln} / \mathrm{Val}$ & $2.06(1.68,2.38)$ & Lac/Gln & $3.92(3.02,5.27)$ \\
\hline Ile/Leu & $0.38(0.32,0.46)$ & Lac/Pyr & $27(18,46)$ \\
\hline Ile/Tyr & $1.08(0.87,1.40)$ & Pyr/Cit & $0.90(0.58,1.36)$ \\
\hline Ile/Val & $0.29(0.25,0.35)$ & $\mathrm{AcO} / \mathrm{AcAcO}$ & $0.23(0.12,0.32)$ \\
\hline Leu/Tyr & $2.71(2.25,3.21)$ & n3_HBut/AcAcO & $2.43(1.84,2.97)$ \\
\hline Leu/Val & $0.74(0.69,0.84)$ & n3_HBut/AcO & $11(6,19)$ \\
\hline Tyr/Nal & $0.27(0.23,0.33)$ & Ile/Glc & $0.014(0.012,0.017)$ \\
\hline Ala/Cit & $4.61(2.27,7.95)$ & Leu/Glc & $0.036(0.032,0.045)$ \\
\hline Ala/Pyr & $3.9(2.6,7.5)$ & Val/Glc & $0.048(0.043,0.057)$ \\
\hline Ala/Glc & $0.057(0.049,0.070)$ & Gln/Glu & $2.93(2.41,3.46)$ \\
\hline
\end{tabular}

Note: Ala/Gln — alanine/glutamine, Ala/Leu — alanine/leucine, Ala/lle — alanine/isoleucine, Ala/Tyr — alanine/tyrosine, Ala/Val — alanine/valine, Gln/Leu — glutamine/ leucine — glutamine/leucine/tyrosine, Gln/Val — glutamine/valine, Ile/Leu — isoleucine/leucine, Ile/Tyr — isoleucine/tyrosine, lle/Val — isoleucine/valine, Leu/Tyr — leucine/tyrosine, Leu/Val — leucine/valine, Tyr/Nal — tyrosine/valine, Ala/Pyr — alanine/pyruvate, Ala/Glc — alanine/glucose, Glc/Cit — glucose/citrate, Gln/Cit — glutamine/citrate, Glc/Pyr — glucose/pyruvate, Gln/Glc — glutamine/glucose, Gln/Pyr — glutamine/ pyruvate, Lac/Ala — lactate/alanine, Lac/Cit — lactate/citrate, Lac/Glc — lactate/glucose, Lac/Gln — lactate/glutamine, Lac/Pyr — lactate/pyruvate, Pyr/Cit — pyruvate/citrate, AcO/AcAcO — acetate/acetoacetic acid, n3_Hbut/ AcAcO — n3_Hydroxybutyrate/acetoacetic acid, n3_Hbut/AcO — n3_Hydroxyglucine/acetate, Ile/Glc — isoleucine/glucose, Leu/Glc — leucine/glucose, Val/Glc — valine/glucose, Gln/Glu — glutamine/glutamate.

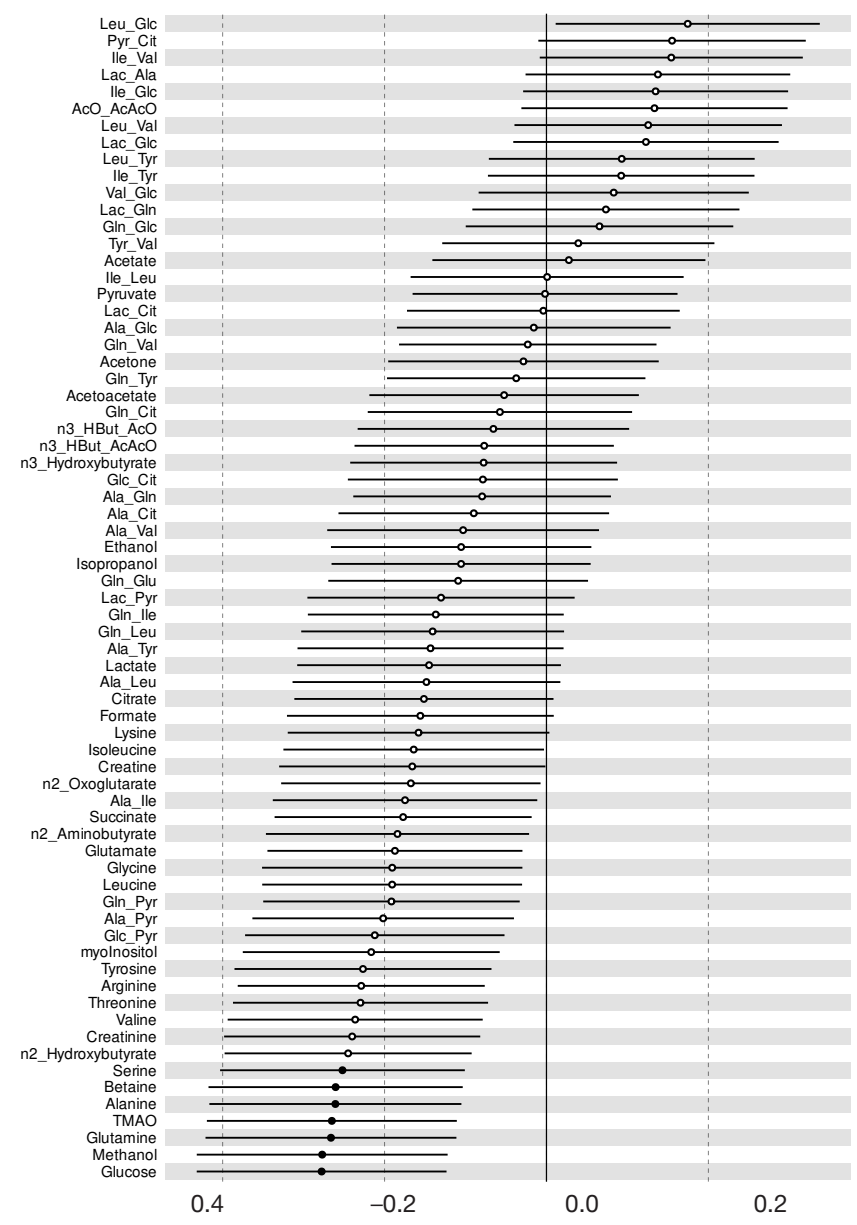

Fig. 2. Forest diagram summarizing all calculated regression models. The models are sorted by their standardized ratios ( $x$-axis). Statistically significant (after adjustment for multiple testing) models are highlighted (filled dots) 
Table 4. Summary of the regression models shown in Figure 3

\begin{tabular}{|c|c|c|c|c|}
\hline Outcome & St. $\beta$ (SE) & F-statistic & Adjusted R2 & $\operatorname{Pr}(>\operatorname{Chi})$ \\
\hline Glucose & $-0.277(0.078)$ & 4.483 & 0.137 & 0.0008 \\
\hline Methanol & $-0.277(0.079)$ & 4.267 & 0.129 & 0.0008 \\
\hline Glutamine & $-0.266(0.079)$ & 4.261 & 0.129 & 0.001 \\
\hline TMAO & $-0.265(0.078)$ & 4.456 & 0.136 & 0.001 \\
\hline Alanine & $-0.261(0.079)$ & 4.036 & 0.121 & 0.002 \\
\hline Betaine & $-0.260(0.080)$ & 3.606 & 0.106 & 0.002 \\
\hline Serine & $-0.252(0.077)$ & 5.548 & 0.171 & 0.002 \\
\hline
\end{tabular}

Note: St. $\beta$ St. - standardized $\beta$.

as a predictor. To correct for the known confounding factors, we added age and BMI as the model terms. All the values were scaled to enable a direct comparison of the magnitude of associations between all metabolites and their relationships. Figure 2 shows a summary of all the models. The data sorting criterium is the standardized coefficient values (descending). Filled dots correspond to the statistically significant models (correction for multiple hypothesis testing was factored in for the statistical significance $p$ ). The model characteristics for each significant association are given in Table 4 and Fig. 3.

\section{DISCUSSION}

The main goal of this study is to explore the associations between the measured values of CA125 and concentrations of plasma metabolites within a homogeneous group of the patients with clinically confirmed high grade ovarian cancer. The results indicate that CA125 levels are inversely associated with several plasma metabolites (see Fig. 2). Of all the associations, only the presence of methanol could raise questions. Nevertheless, methanol is a normal component of human plasma [9]. Its origin is mostly dietary (consumption of fresh fruits and fermented drinks); intestinal microflora also contributes to its generation. Under normal conditions, such low or "physiological" methanol concentrations are metabolized in the liver [10]. The negative association between methanol and CA125 appears to be contra intuitive, but changes in the patients' dietary habits and decreased microbiota activity at the late stages of cancer may explain this observation. The significant negative relationship between CA125 and trimethylamine oxide, which is often interpreted as a microbiota-specific metabolite [11], serves as an additional argument in favor of the microbiotic origin of methanol. All other significant associations (glucose, glutamine, alanine, betaine, and serine) are in agreement with the changes in the systemic metabolism at the advanced stages of malignancy. While the phenomenon of glucose and amino acids (especially glutamine and alanine) depletion in the body fluids of the cancer patients

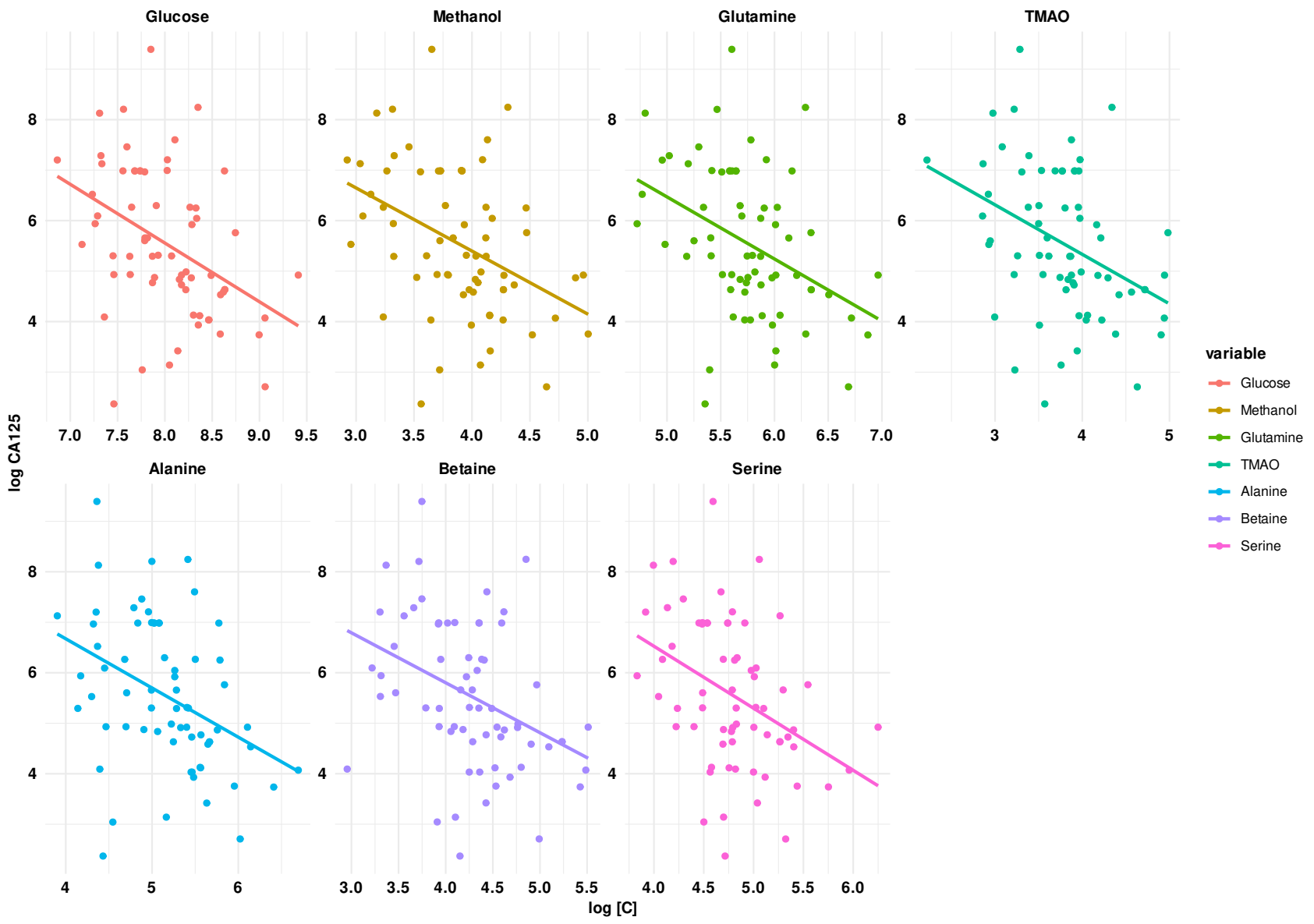

Fig. 3. Scatter plots with regression lines illustrating statistically significant dependences of CA125 on metabolite concentrations 
has been reported many times, the detailed physiological mechanism of the effect remain unexplored. The decrease of alanine with a progression of malignancy cloud be explained by its increased utilization as a major gluconeogenic precursor, to meet the high glucose consumption by the tumor cells [12]. A decrease in the level of glutamine may be associated with more active glutaminolysis, which is required to provide precursors for the synthesis of nucleic acids $[12,13]$. There is no simple mechanistic explanation for the role of betaine in the physiology of malignant neoplasms. However, a recent meta-analysis has shown that betaine levels reduce the risk of cancer [14]. Indeed, as the main donor of the methyl group in the conversion of homocysteine to methionine, betaine plays a significant role in pathologies associated with altered systemic metabolism of homocysteine, folic acid, and B vitamins. Cancer, or more specifically ovarian cancer is just one of them.

Yet, looking into the model metrics for the each association (Table 4, Fig. 3) we cannot ignore the fact that despite being significant the models cover only between 10 and $15 \%$ of the variance in the data (adjusted R2). Such "noisy" models are revealing the main weakness of our study, namely a rather limited pool of the patients. Another possible source of the noise is unaccounted confounding factors. In fact, while for all patients included in the current report the samples were collected before initiation of the treatment, there is no realistic way to control their dietary history and the history of medicament use before the admission.

\section{CONCLUSIONS}

The study allowed identifying statistically significant associations between the measured (log) values of CA125 epitope and the plasma concentrations of a number of metabolites. Showing a link between the CA125 plasma values and metabolic composition of the plasma we for the first time describe a metabolic "footprint" of the circulated mucins. This, in its turn, allows suggesting inclusion of metabolic indicators into the CA125-based OC progress assessment.

Since CA125 discovery our understanding of ovarian cancer biology has changed to the point that these tumors are classified not only by histological attributes, but also (and mainly) on the basis their molecular phenotype. Thus, the gradual integration of metabolic parameters into the list of diagnostic methods used for stage I-IV OC is only logical.

\section{References}

1. Hollingsworth MA, Swanson BJ. Mucins in cancer: protection and control of the cell surface. Nat Rev Cancer. 2004; 4 (1): 45-60. DOI: 10.1038/NRC1251

2. Yin BWT, Dnistrian A, Lloyd KO. Ovarian cancer antigen CA125 is encoded by the MUC16 mucin gene. Int J cancer. 2002; 98 (5): 737-40. DOI: 10.1002/IJC.10250.

3. Devine PL, McGuckin MA, Ward BG. Circulating mucins as tumor markers in ovarian cancer (review). Anticancer Res. 1992; 12 (3): 709-17. Accessed November 27, 2021. Available from: https:// www.researchgate.net/publication/21533861_Circulating_ mucins_as_tumor_markers_in_ovarian_cancer_Review.

4. Pavlovich SV, Yurova MV, Melkumyan AG, Frankevich VE, Chagovets W, Khabas GN. Biomarkers in ovarian neoplasms: opportunities, limitations, and prospects for using in reproductiveaged women. Akush Ginekol (Sofiia). 2019; 11 (2019): 65-73. DOI: 10.18565/aig.2019.11.65-73.

5. Felder M, Kapur A, Gonzalez-Bosquet J, et al. MUC16 (CA125): tumor biomarker to cancer therapy, a work in progress. Mo Cancer. 2014: 13 (1): 1-15. DOI: 10.1186/1476-4598-13-129.

6. Seyfried TN, Flores RE, Poff AM, D'Agostino DP. Cancer as a metabolic disease: implications for novel therapeutics. Carcinogenesis. 2014; 35 (3): 515. DOI:10.1093/CARCIN/BGT480.

7. Coller HA. Is Cancer a Metabolic Disease? Am J Pathol. 2014 184 (1): 4. DOI:10.1016/J.AJPATH.2013.07.035.

\section{Литература}

1. Hollingsworth MA, Swanson BJ. Mucins in cancer: protection and control of the cell surface. Nat Rev Cancer. 2004; 4 (1): 45-60. DOI: 10.1038/NRC1251.

2. Yin BWT, Dnistrian A, Lloyd KO. Ovarian cancer antigen CA125 is encoded by the MUC16 mucin gene. Int J cancer. 2002; 98 (5): 737-40. DOI: 10.1002/IJC.10250.

3. Devine PL, McGuckin MA, Ward BG. Circulating mucins as tumor markers in ovarian cancer (review). Anticancer Res. 1992; 12 (3): 709-17. Accessed November 27, 2021. Available from: https:// www.researchgate.net/publication/21533861_Circulating_ mucins as tumor markers in ovarian cancer Review.

4. Pavlovich SV, Yurova MV, Melkumyan AG, Frankevich VE, Chagovets W, Khabas GN. Biomarkers in ovarian neoplasms: opportunities, limitations, and prospects for using in reproductive-

8. Kaprin AD, Starinskij W, Shahzadova AO, redaktory. Sostojanie onkologicheskoj pomoshhi naseleniju Rossii v 2019 godu. M.: MNIOI im. P. A. Gercena — filial FGBU «NMIC radiologii», 2020; 239 s. Russian.

9. Psychogios N, Hau DD, Peng J, et al. The Human Serum Metabolome. PLoS One. 2011; 6 (2): e16957. DOI: 10.1371/ JOURNAL.PONE.0016957.

10. Dorokhov YL, Shindyapina AV, Sheshukova EV, Komarova TV. Metabolic methanol: molecular pathways and physiological roles. Physiol Rev. 2015; 95 (2): 603-44. DOI: 10.1152/PHYSREV.00034.2014.

11. Tang WHW, Wang Z, Kennedy DJ, et al. Gut microbiotadependent trimethylamine $\mathrm{N}$-oxide (TMAO) pathway contributes to both development of renal insufficiency and mortality risk in chronic kidney disease. Circ Res. 2015; 116 (3): 448-55. DOI: 10.1161/CIRCRESAHA.116.305360.

12. Lai HS, Lee JC, Lee PH, Wang ST, Chen WJ. Plasma free amino acid profile in cancer patients. Semin Cancer Biol. 2005; 15 (4): 267-76. DOI: 10.1016/J.SEMCANCER.2005.04.003.

13. Altman BJ, Stine ZE, Dang CV. From Krebs to clinic: glutamine metabolism to cancer therapy. Nat Rev Cancer. 2016; 16 (10): 619-34. DOI: 10.1038/NRC.2016.71.

14. Youn J, Cho E, Lee JE. Association of choline and betaine levels with cancer incidence and survival: A meta-analysis. Clin Nutr. 2019; 38 (1): 100-09. DOI: 10.1016/J.CLNU.2018.01.042.

aged women. Akush Ginekol (Sofiia). 2019; 11 (2019): 65-73. DOI: 10.18565/aig.2019.11.65-73.

5. Felder M, Kapur A, Gonzalez-Bosquet J, et al. MUC16 (CA125): tumor biomarker to cancer therapy, a work in progress. Mol Cancer. 2014; 13 (1): 1-15. DOI: 10.1186/1476-4598-13-129.

6. Seyfried TN, Flores RE, Poff AM, D'Agostino DP. Cancer as a metabolic disease: implications for novel therapeutics. Carcinogenesis. 2014; 35 (3): 515. DOI:10.1093/CARCIN/BGT480.

7. Coller HA. Is Cancer a Metabolic Disease? Am J Pathol. 2014; 184 (1): 4. DOI:10.1016/J.AJPATH.2013.07.035.

8. Каприн А. Д., Старинский В. В., Шахзадова А. О., редакторы. Состояние онкологической помощи населению России В 2019 году. М.: МНИОИ им. П. А. Герцена - филиал ФГБУ «НМИЦ радиологии», 2020; 239 с. 
9. Psychogios N, Hau DD, Peng J, et al. The Human Serum Metabolome. PLoS One. 2011; 6 (2): e16957. DOI: 10.1371/ JOURNAL.PONE.0016957.

10. DorokhovYL, ShindyapinaAV, SheshukovaEV, Komarova TV. Metabolic methanol: molecular pathways and physiological roles. Physiol Rev. 2015; 95 (2): 603-44. DOI: 10.1152/PHYSREV.00034.2014.

11. Tang WHW, Wang Z, Kennedy DJ, et al. Gut microbiotadependent trimethylamine $\mathrm{N}$-oxide (TMAO) pathway contributes to both development of renal insufficiency and mortality risk in chronic kidney disease. Circ Res. 2015; 116 (3): 448-55. DOI:
10.1161/CIRCRESAHA.116.305360

12. Lai HS, Lee JC, Lee PH, Wang ST, Chen WJ. Plasma free amino acid profile in cancer patients. Semin Cancer Biol. 2005; 15 (4): 267-76. DOI: 10.1016/J.SEMCANCER.2005.04.003.

13. Altman BJ, Stine ZE, Dang CV. From Krebs to clinic: glutamine metabolism to cancer therapy. Nat Rev Cancer. 2016; 16 (10): 619-34. DOI: 10.1038/NRC.2016.71.

14. Youn J, Cho E, Lee JE. Association of choline and betaine levels with cancer incidence and survival: A meta-analysis. Clin Nutr. 2019; 38 (1): 100-09. DOI: 10.1016/J.CLNU.2018.01.042. 